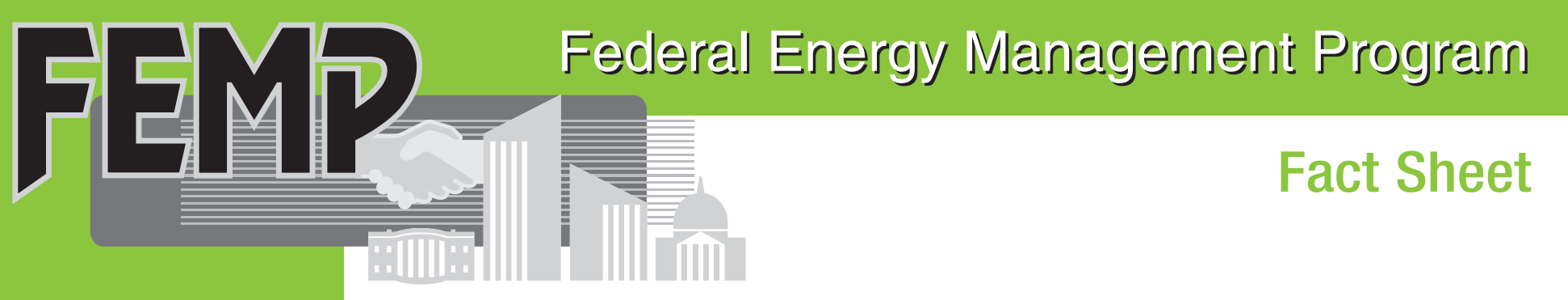

Leading by example,

saving energy and

taxpayer dollars in

federal facilities

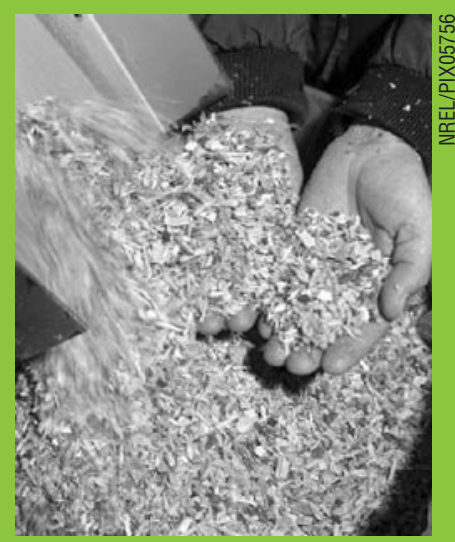

This chipped wood can be used for direct combustion, gasification, or co-firing.

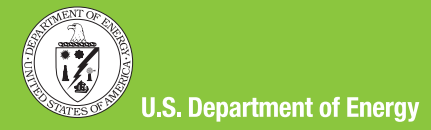

Energy Efficiency and Renewable Energy Bringing you a prosperous future where energy is clean, abundant, reliable, and affordable

\title{
Biomass Resources for the Federal Sector
}

Biomass resources provide opportunities to
meet these federal renewable energy goals:

- EO 13123 - Greening the Government through Energy-efficient Management

Achieve the equivalent of $2.5 \%$ of federal facility electrical energy from renewable sources by 2005

\section{- EO 13134 - Developing and Promoting Biobased Products and Bioenergy}

Stimulate creation and early adoption of technologies needed to make biobased products and bioenergy cost competitive

\section{What is biomass?}

Biomass fuels include any organic matter that is available on a renewable or recurring basis, such as dedicated energy crops, agricultural or forest residues, animal waste, and other waste materials. Alternative methane fuels include landfill methane, wastewater treatment digester gas, and coal-bed methane. The definition of biomass for meeting Executive Order 13123 is from the "Biomass Research and Development Act of 2000" and includes municipal solid waste and landfill gas.

Biomass fuels are diverse in nature and in location. They can be solid like wood chips, liquid like biodiesel or ethanol, or gaseous like landfill gas. Biomass fuels can be used in place of fossil fuels in most conventional energy applications, such as steam boilers, water heaters, generators, gas turbines, and vehicle engines.

\section{Why use biomass?}

A primary advantage of biomass fuel compared to intermittent solar or wind power is that biomass fuel is easily stored and can provide heat and/or electricity whenever it is needed. Currently, the United States has more than 9,733 MW of electrical generating capacity from biomass. In 2001, biomass supplanted hydropower as the largest source of domestic renewable energy.

Biomass fuels provide benefits over fossil fuels in various ways depending on the resource and application. These benefits can include increased domestic energy security, reduced energy imports, enhanced local energy economies, diversified energy sources, decreased emissions, waste stream reduction, and rural and agricultural economic development.

Although federal facilities can use any available biomass resource, three biomass resources are well suited for federal uses. The first is the large resources near federal facilities targeted in the resource assessment mentioned below and available through the FEMP Biomass and Alternative Methane Fuels (BAMF) Super Energy Savings Performance Contract (Super ESPC). Second, the use of biodiesel and renewable alternative fuels in federal fleets provide a growing opportunity to meet renewable and alternative fuel goals. A third large resource that has not yet been widely tapped is the biomass resulting from the U.S. Forest Service and Bureau of Land Management treating (thinning) millions of acres annually as part of the National Fire Plan.

\section{What are the opportunities for using biomass or alternative methane fuels in the federal government?}

Because the locations of biomass resources are spread across the country and the resources can be bulky, an important part of using them economically is to use them close to their source to reduce transportation costs. Biomass waste and residues offer compelling energy cost savings compared to conventional fuels, as the material is typically inexpensive and may reduce costs through avoided tipping fees or destructive environmental effects. A new resource assessment 


\section{For More Information: \\ EERE Information Center \\ 1-877-EERE-INF or 1-877-337-3463 \\ www.eere.energy.gov/femp/}

has matched more than 1,000 large federal facilities with nearly 2,500 sources of renewable biomass and alternative methane fuels located nearby. The assessment targeted wood waste, landfills, and wastewater treatment plants because these offer the best nearterm, cost-effective opportunities. The proximity of these resources to federal facilities makes them likely candidates for economically replacing conventional fuels. This assessment of large biomass resources is a useful first-step tool for implementing biomass and alternative methane fuels projects.

Methane from landfills, wastewater treatment plants, coal beds, or coal mines represents a significant source of fuel that is often wasted by being released into the atmosphere or simply flared. Given methane's heat-trapping qualities and the potential impact on climate change, using it as a fuel has both economic and environmental benefits. The BAMF Super ESPC financing mechanism can help federal agencies develop and finance projects to take advantage of these local resources while reducing energy costs and achieving federal renewable energy goals. The bioenergy produced can be used by federal facilities or by private companies, in facilitated renewable energy development projects, and still count toward federal renewable energy goals.

\section{How is biodiesel used in federal fleets?}

Federal fleets that run on biofuels_-ethanol and biodiesel-help reduce the environmental emissions associated with some transportation fuels.

Biodiesel is a renewable, environmentally friendly biofuel that has recently begun to transform the federal diesel fuel market. Federal consumption of biodiesel has increased from 113,760 GGE (gasoline gallons equivalent) of B100 in 2000 to 783,400 GGE in 2003. Biodiesel, primarily made from soybeans, is typically used as a blend of petroleum diesel and pure biodiesel. It is commonly available as B20-a blend of $20 \%$ biodiesel and $80 \%$ diesel fuel. In its pure form, $100 \%$ biodiesel, or B100, is renewable, biodegradable, nontoxic, and has a high flash point, making it a very safe fuel to use, handle, and store. Biodiesel has low life-cycle global warming gas emissions, and compared to petroleum diesel, has lower emissions of particulate matter, carbon monoxide, and unburned hydrocarbons.

Federal agencies covered by the requirements of EPAct of 1992 can receive one alternative fuel vehicle (AFV) credit for using 450 gallons of B100 or 2,250 gallons of B20 for up to $50 \%$ of their annual requirement. To receive credit, agencies must use a minimum of B20.

\section{Where is biodiesel being used?}

B20 is now in use in more than 130 major fleets, including 62 federal fleets. The performance characteristics of B20 are essentially the same as with diesel, but with added emissions benefits.

Federal agencies can purchase B20 through the Defense Energy Support Center at prices similar to those of diesel (\$0.90/gal in 2004), through their direct delivery fuels purchase program.

\section{How can biomass be developed from forest thinning and other woody waste?}

Huge quantities of biomass are available from the U.S. Forest Service and Bureau of Land Management treating (thinning) millions of acres annually as part of the National Fire Plan. The beneficial use of biomass from forest residues applies to multiple stakeholders-federal agencies, local communities, and the private sector-and results in local development of a cost-effective, sustainable fuel source along with safer communities and healthier forests. These treatments represent a very significant source of biomass fuel that can be a reliable, sustainable fuel source to provide heat and/or electricity on a continuous or as-needed basis. Additionally, significant quantities of wood waste are available in urban and suburban areas. The economics of individual sites will depend on the biomass fuel resource quality and sustainability, transportation distance, and the fuel that it is replacing or being compared to. In facilities that burn coal for energy, woody biomass can be used to co-fire up to $10-15 \%$ of the fuel supply, which reduces harmful emissions and produces less ash.

\section{For more information}

Federal Energy Management Program-

Renewable Energy:

www.eere.energy.gov/femp/technologies/renewable energy.cfm

\section{BAMF Super ESPC Financing:}

www.eere.energy.gov/femp/financing/superespcs biomass.cfm

DOE Alternative Fuels Data Center:

www.eere.energy.gov/afdc/

DOE Biomass Program:

www.eere.energy.gov/biomass
A Strong Energy Portfolio for a Strong America

Energy efficiency and clean, renewable energy will mean a stronger economy, cleaner environment, and greater energy independence for America. Working with a wide array of state, community, industry, and university partners, the U.S. Department of Energy's Office of Energy Efficiency and Renewable Energy invests in a diverse portfolio of energy technologies.

\section{Contacts}

Anne Sprunt Crawley

U.S. Department of Energy

Federal Energy Management Program

Phone: 202-586-1505

E-mail: Anne.Crawley@ee.doe.gov

Christopher Abbuehl

National Biomass and Alternative

Methane Fuels (BAMF) Program

Representative

DOE Mid-Atlantic Regional Office

Phone: 215-656-6995

E-mail: Christopher.abbuehl@

ee.doe.gov

Pamela Serino, Chemist

Defense Energy Support Center

Phone: 703-767-8363

E-mail: pamela.serino@dla.mil

Robi Robichaud

National Renewable Energy

Laboratory

Federal Energy Management Program

Phone: 303-384-7553

E-mail: robi_robichaud@nrel.gov

\section{i\% \\ U.S. Department of Energy \\ Energy Efficiency and Renewable Energy}

Bringing you a prosperous future where energy is clean, abundant, reliable, and affordable

Produced for the U.S. Department of Energy by the National Renewable Energy Laboratory, a DOE national laboratory

DOE/G0-102005-2000

August 2005 